\section{Supplemental Foliar Potassium Applications with or without a Surfactant can Enhance Netted Muskmelon Quality}

\author{
Gene E. Lester ${ }^{1}$ \\ U.S. Department of Agriculture, Agricultural Research Service, Kika de la \\ Garza Subtropical Agricultural Research Center, 2413 East Highway 83, \\ Building 200, Weslaco, TX 78596 \\ John L. Jifon \\ Texas A\&M University, Texas Agricultural Experiment Station, 2415 East \\ Highway 83, Weslaco, TX 78596 \\ D. J. Makus \\ U.S. Department of Agriculture, Agricultural Research Service, Kika de la \\ Garza Subtropical Agricultural Research Center, 2413 East Highway 83, \\ Building 201, Weslaco, TX 78596 \\ Additional index words. Cucumis melo L. (Reticulatus group), ascorbic acid, $\beta$-carotene, \\ color, firmness, sugars, soluble solids, pressure potential
}

\begin{abstract}
Netted muskmelon [Cucumis melo L. (Reticulatus Group)] fruit quality (ascorbic acid, $\beta$-carotene, total free sugars, and soluble solids concentration (SSC)) is directly related to plant potassium (K) concentration during fruit growth and maturation. During reproductive development, soil $\mathrm{K}$ fertilization alone is often inadequate due to poor root uptake and competitive uptake inhibition from calcium and magnesium. Foliar applications of glycine-complexed $\mathrm{K}$ during muskmelon fruit development has been shown to improve fruit quality, however, the influence of organic-complexed $\mathrm{K}$ vs. an inorganic salt form has not been determined. This glasshouse study investigated the effects of two K sources: a glycine-complexed $\mathrm{K}$ (potassium metalosate, $\mathrm{KM}$ ) and potassium chloride (KCl) (both containing $800 \mathrm{mg} \mathrm{K} / \mathrm{L}$ ) with or without a non-ionic surfactant (Silwet L77) on melon quality. Orange-flesh muskmelon 'Cruiser' was grown in a glasshouse and fertilized throughout the study with soil-applied N-P-K fertilizer. Starting at 3 to $5 \mathrm{~d}$ after fruit set, and up to 3 to $5 \mathrm{~d}$ before fruit maturity at full slip, entire plants were sprayed weekly, including the fruit, with $\mathrm{KM}$ or $\mathrm{KCl}$ with or without a surfactant. Fruit from plants receiving supplemental foliar $\mathrm{K}$ had significantly higher $\mathrm{K}$ concentrations in the edible middle mesocarp fruit tissue compared to control untreated fruit. Fruit from treated plants were also firmer, both externally and internally, than those from non-treated control plants. Increased fruit tissue firmness was accompanied by higher tissue pressure potentials of $K$ treated plants vs. control. In general, $K$ treated fruit had significantly higher SSC, total sugars, total ascorbic acid, and $\beta$-carotene than control fruit. Fall-grown fruit generally had higher SSC, total sugars, total ascorbic acid and $\beta$ carotene concentrations than spring-grown fruit regardless of $K$ treatment. The effects of surfactant were not consistent but in general, addition of a surfactant tended to affect higher SSC and $\beta$-carotene concentrations.
\end{abstract}

With the exception of nitrogen, potassium is required by plants in much greater amounts than all the other soil-supplied nutrients (Tisdale et al., 1985). Adequate supply of fertilizer potassium is necessary for sustainable crop

Received for publication 22 Nov. 2005. Accepted for publication $9 \mathrm{Feb}$. 2006. This research was funded by the USDA-ARS under CRIS No. 620443000-014-00D, and by the Potash and Phosphate Institute to G.E.L. Technical assistance of R. Meyer, Paul Thompson, Jr. (USDA-ARS, Weslaco, Texas) and Y. Luna (TAES, Weslaco, Texas) is gratefully acknowledged. Use of company or product names by the USDA does not imply approval or recommendation of the product to the exclusion of others that may be suitable.

${ }^{1}$ To whom reprint requests should be addressed; e-mail glester@weslaco.ars.usda.gov. production. Plants obtain K primarily from the soil in the form of $\mathrm{K}^{+}$which is also strongly adsorbed by soil components, particularly clay particles and is, therefore, not readily mobile in most soils (Brady, 1984; Tisdale, et al., 1985).

Potassium uptake by plants from the soil solution is regulated by several factors including texture, moisture conditions, $\mathrm{pH}$, aeration, and temperature (Mengel and Kirkby, 1980; Tisdale et al., 1985). Clay soils can adsorb and hold more $\mathrm{K}$ and exchange it with the soil solution for plant uptake than sandy soils. Both calcium and magnesium compete with $\mathrm{K}$ for root uptake, hence plants grown in these soils often exhibit $\mathrm{K}$ deficiencies even though soil analyses indicate adequate K. Furthermore, neutral and acid soils tend to have a higher capacity to release $\mathrm{K}$ into the soil solution than alkaline soils. Increasing soil moisture increases movement of $\mathrm{K}$ to plant roots and enhances availability. However, in waterlogged soil, root activity declines due to poor aeration, thereby decreasing $\mathrm{K}$ uptake. Adequate soil aeration is, therefore, necessary to supply oxygen for root respiration and $\mathrm{K}$ uptake. Optimum soil temperature for nutrient uptake is $20-30^{\circ} \mathrm{C}$ (Tisdale et al., 1985). Low ( $<20$ $\left.{ }^{\circ} \mathrm{C}\right)$ and high $\left(>30^{\circ} \mathrm{C}\right)$ soil temperatures can impair root physiological processes involved in $\mathrm{K}$ uptake.

Plant developmental stage also influences the capacity for $\mathrm{K}$ uptake. More $\mathrm{K}$ is taken up during vegetative growth stages when roots are more active than in reproductive growth stages (Beringer et al., 1986). Developing fruit are stronger sinks for photoassimilates than roots and other vegetative tissues. This competition for photoassimilates reduces root growth and energy supply for nutrient uptake including $\mathrm{K}$ (Marschner, 1995). Therefore, during reproductive development, soil K supply is seldom adequate to support crucial processes such as sugar transport from leaves to fruit, enzyme activation, protein synthesis, and cell extension that ultimately determine fruit yield and quality. Additionally, muskmelons have some of the highest fruit $\mathrm{K}$ concentrations among fruit (www.nal.usda.gov/fnic/foodcomp/), hence developing melon fruit have a high demand for $\mathrm{K}$ and often rely on re-translocation from vegetative tissues (Williams and Kafkafi, 1998).

Previous research has demonstrated that this apparent $\mathrm{K}$ deficiency during fruit development and maturation can be mitigated through supplemental foliar K applications to netted muskmelon (Lester et al., 2005) and cotton (Howard et al., 1998). Lester et al. (2005) showed that foliar applied glycine amino acidcomplexed K sprayed weekly throughout fruit growth and maturation significantly increased netted muskmelon fruit firmness, ascorbic acid, free sugar, and $\beta$-carotene concentrations.

The effect of $\mathrm{K}$ on firmness is most likely different from that of $\mathrm{Ca}$ since $\mathrm{K}$ is not a structural component of plant tissues. Calcium is thought to influence firmness through its interaction with the cell wall constituents (pectin) to maintain both cell wall and membrane integrity (Glenn and Poovaiah, 1990).

Differences in tissue firmness could also be related to changes in tissue hydrostatic pressure (turgor) (Shackel et al., 1991) mediated by osmolytes such as K. Foliar K fertilization of tomatoes (Lycopersicon esculentum Mill.) has also been shown to increase fruit firmness (Chapagain and Wiesman, 2004). However, it is unclear whether the beneficial effects of foliar $\mathrm{K}$ fertilization on firmness and other quality parameters differ according to the source of K used, including the most common fertilizer $\mathrm{K}$ source-potassium chloride $(\mathrm{KCl})$. Therefore, the objective of this glasshouse study was to investigate the possible mechanisms of the previously observed K-induced fruit firmness of netted muskmelon and to compare two sources of supplemental foliar K-a glycine 
amino acid-complexed $\mathrm{K}$ (potassium metalosate), and $\mathrm{KCl}$, both applied with or without a surfactant. Two experiments were conducted in Fall 2004 and Spring 2005.

\section{Materials and Methods}

Netted, orange-flesh muskmelon 'Cruiser' fruit were grown in a glasshouse following the procedures previously described by Lester et al. (2005). Briefly, plants were grown in 15-L black plastic pots containing a commercial potting medium [Sunshine mix \#2 (Sun Gro Horticulture, Bellevue, Wash.)] in a glasshouse at the U. S. Department of Agriculture, Agricultural Research Service, Kika de la Garza Subtropical Agricultural Research Center, Weslaco, Texas (lat. $26^{\circ} 10^{\prime} \mathrm{N}$, long. $97^{\circ} 58^{\prime} \mathrm{W}$, elevation $21 \mathrm{~m}$ ). Glasshouse air temperature, relative humidity and photosynthetic photon flux (PPF) were monitored and recorded continuously using a micro weather station data logger (model H21-002, Onset Computer, Bourne, Mass.). Following germination (7 d after planting, DAP), seedlings were thinned to one per pot. Mutual shading among plants was minimized by placing pots at least $45 \mathrm{~cm}$ apart. Plants were watered at least once per day using an automatic drip irrigation system, and fertigated two times per week with a complete water-soluble fertilizer $(10 \mathrm{~N}-4.4 \mathrm{P}-8.3 \mathrm{~K}$, Peter's Corp., St. Louis) during vegetative and fruit developmental stages. During flowering and pollination, plants were fertilized two times per week with a $4.5 \mathrm{~N}-9.9 \mathrm{P}-6.3 \mathrm{~K}$ nutrient solution.

Immediately after fruit set (anthesis) and up to fruit maturation (abscission), entire plants including fruit were sprayed to runoff with one of the following K sources: 1) a glycine amino acid-complexed $\mathrm{K}$ solution (potassium metalosate $24 \% \mathrm{~K}$; Albion Advance Nutrition Laboratories, Inc, Clearfield, Utah) containing $800 \mathrm{mg} \mathrm{K} / \mathrm{L}$, (KM), 2) potassium chloride solution $(\mathrm{KCl}, 800 \mathrm{mg} \mathrm{K} / \mathrm{L}), 3) \mathrm{KM}$ plus a nonionic surfactant (Silwet L-77; silicone polyether 100\%; Loveland Ind. Inc. Greeley, Colo.), 4) KCl plus Silwet L-77 surfactant, or $5)$ deionized water. Ascorbic acid, $\beta$-carotene, fruit sugars, fruit firmness, $\mathrm{K}$ concentration, soluble solids concentration were analyzed according to Lester et al. (2005). Fruit firmness expressed as Newtons $(\mathrm{N})$ was measured with a V-tip probe $(1 \mathrm{~cm}$ long $x 5.8 \mathrm{~mm}$ diameter $\mathrm{x} 1 \mathrm{~mm}$ wide) attached to a force gauge (Mark-10, model MG20; Wagner Instr. Co., Greenwhich, Conn.), following $21^{\circ} \mathrm{C}$ storage. External fruit firmness measurements were made at the equatorial region of each fruit; the epidermal tissue was removed using a potato peeler before measurements. Internal firmness measurements were determined on middle-mesocarp tissue from one half of an equatorially-cut fruit. During Spring 2005 repetition of the study, fruit tissue water relations were determined by thermocouple psychrometry (Boyer, 1969). Briefly, three melon cord sections with epidermis removed, and corresponding to the opposite half where firmness measurements were taken, were used for pressure potential $\left(\psi_{\mathrm{p}}\right)$ determinations. A radial core section (about $0.5 \mathrm{~cm}$ length) was removed from each subsample using a \# 7 cork borer. Each subsample was blotted lightly with clean lint-free tissue paper to remove surface solutes, then placed in a stainless-steel cup, and inserted into a thermocouple sample chamber (model SC-10; Decagon Devices, Pullman, Wash.). After an equilibration period of 30 min., water potential $\left(\psi_{w}\right)$ was read with a nanovolt meter (Tru-Psi water potential meter, Decagon Devices, Pullman, Wash.). Following $\psi_{w}$ measurements, samples were placed in 1.5 $\mathrm{mL}$ microcentrifuge tubes and subjected to a freeze-thaw cycle and solutes extracted by spinning at $2000 g_{n}$ for $5 \mathrm{~min}$ at $20^{\circ} \mathrm{C}$. Aliquots $(100 \mu \mathrm{L})$ of the extracted samples were used for solute potential $\left(\psi_{\mathrm{s}}\right)$ determinations following the same procedures as those for $\psi_{\mathrm{w}}$ determination. Pressure potential $\left(\psi_{\mathrm{p}}\right)$ was calculated from the following relationship: $\psi_{\mathrm{p}}$ $=\psi_{\mathrm{w}}-\psi_{\mathrm{s}}$.

Experimental design and data analysis. A completely randomized design with ten single plants per treatment and one melon fruit per plant was used in both spring and fall repetitions of this study. Data were subjected to analysis of variance using the general linear model (GLM) procedure of SAS (SAS, Cary, N.C.). Treatment means were compared using the least square means (LSMEANS) procedure of SAS. Fruit were held at room temperature $\left(25^{\circ} \mathrm{C}\right.$ and about $50 \% \mathrm{RH}$ ) for about $3 \mathrm{~d}$ before processing to simulate commercial retail practices. The actual time in storage was used as a covariate in the water potential data analyses using the PROC MIXED procedure in SAS (Ver. 8.2).

\section{Results and Discussion}

Glasshouse temperatures during the fruit development and maturation periods ranged from 26.7 to $40.2^{\circ} \mathrm{C}$ in Fall 2004, and from 21.1 to $34.8{ }^{\circ} \mathrm{C}$ in Spring 2005. Average relative humidity values were similar (about $55 \%$ ) during both experiments. However, the average daily PPF in Fall 2004 (18.1 \pm 0.68 $\left.\mathrm{mol} \cdot \mathrm{m}^{-2} \cdot \mathrm{d}^{-1}\right)$ was less than the average for Spring $2005\left(21.4 \pm 0.79 \mathrm{~mol} \cdot \mathrm{m}^{-2} \cdot \mathrm{d}^{-1}\right)$ due to frequent cloudy days in fall, the rainy season period at Weslaco.

Foliar K applications during fruit growth and maturation generally resulted in higher $\mathrm{K}$ concentrations in fruit middle-mesocarp tissue compared to non-treated control fruit (Table 1). In both spring and fall, the effects of $\mathrm{K}$ source and surfactant use on fruit tissue K concentrations were generally not consistent.

External (under the epidermis) and internal mesocarp firmness of fruit from plants receiving supplemental foliar K were significantly higher than those fruit from control plants in both seasons regardless of surfactant use or source of K (Table 1). Similar beneficial effects of foliar K (from monopotassium phosphate) on fruit firmness have also been shown on tomatoes (Lycopersicon esculentum Mill.) (Chapagain and Wiesman, 2004), but the potential mechanisms for this effect have not been investigated. It is unlikely that increased melon fruit firmness is due to greater membrane integrity, as is the case with exogenouslyapplied calcium (Lester and Grusak, 1999), since $\mathrm{K}$ does not form part of any structural components of plant tissues as does $\mathrm{Ca}$ (Cooke and Clarkson, 1992). A plausible mechanism for the $\mathrm{K}$ related increase in fruit firmness is increased fruit tissue pressure potential $\left(\psi_{\mathrm{p}}\right)$ (Table 1). Mesocarp tissue $\psi_{\mathrm{p}}$ was significantly higher in all K-treated, compared to nontreated

Table 1. Influence of growing season (spring or fall) and two sources of supplemental foliar K-A glycine amino acid-complexed K, Potassium Metalosate (KM) and potassium chloride $(\mathrm{KCl})$ applied with or without a surfactant $(\mathrm{S})$ on fruit potassium concentration, fruit firmness and (spring only) fruit tissue pressure potential $\left(\Psi_{\mathrm{p}}\right)$ of netted muskmelon 'Cruiser'.

\begin{tabular}{|c|c|c|c|c|c|c|}
\hline Treatment & \multicolumn{3}{|c|}{$\begin{array}{l}\text { Tissue K concn } \\
\left(\mathrm{mg} \cdot \mathrm{g}^{-1} \text { fresh wt }\right)\end{array}$} & \multicolumn{2}{|c|}{$\begin{array}{l}\text { Fruit tissue firmness } \\
(\mathrm{N})\end{array}$} & $\begin{array}{c}\text { Fruit } \Psi_{\mathrm{p}} \\
(\mathrm{MPa})\end{array}$ \\
\hline \multicolumn{7}{|l|}{ Fall 2004} \\
\hline $\mathrm{KCl}$ & $3.54 \mathrm{a}$ & $2.07 \mathrm{bc}$ & $2.30 \mathrm{~b}$ & $19.7 \mathrm{a}$ & $10.7 \mathrm{a}$ & --- \\
\hline $\mathrm{KM}+\mathrm{S}$ & $3.30 \mathrm{~b}$ & $2.50 \mathrm{a}$ & $2.41 \mathrm{a}$ & $18.8 \mathrm{a}$ & $11.5 \mathrm{a}$ & --- \\
\hline $\mathrm{KCl}+\mathrm{S}$ & $3.35 \mathrm{~b}$ & $2.25 \mathrm{~b}$ & $2.45 \mathrm{a}$ & $19.2 \mathrm{a}$ & $12.0 \mathrm{a}$ & --- \\
\hline Control & $3.29 \mathrm{~b}$ & $1.89 \mathrm{c}$ & $2.17 \mathrm{c}$ & $14.5 \mathrm{~b}$ & $8.6 \mathrm{~b}$ & --- \\
\hline $\mathrm{KCl}$ & $4.49 \mathrm{a}$ & $2.74 \mathrm{bc}$ & $2.55 \mathrm{~b}$ & $15.7 \mathrm{a}$ & $9.6 \mathrm{~b}$ & $0.030 \mathrm{c}$ \\
\hline $\mathrm{KM}+\mathrm{S}$ & $3.72 \mathrm{~b}$ & $3.12 \mathrm{ab}$ & $2.60 \mathrm{~b}$ & $16.8 \mathrm{a}$ & $10.0 \mathrm{ab}$ & $0.067 \mathrm{a}$ \\
\hline $\mathrm{KCl}+\mathrm{S}$ & $3.64 \mathrm{~b}$ & $3.40 \mathrm{a}$ & $2.60 \mathrm{~b}$ & $17.7 \mathrm{a}$ & $11.1 \mathrm{a}$ & $0.075 \mathrm{a}$ \\
\hline Control & $3.65 \mathrm{~b}$ & $2.66 \mathrm{c}$ & $2.35 \mathrm{c}$ & $12.7 \mathrm{~b}$ & $7.5 \mathrm{c}$ & $0.000 \mathrm{~d}$ \\
\hline
\end{tabular}

${ }^{2}$ The $\Psi_{\mathrm{p}}$ for control was set to zero and all other values adjusted upward accordingly.

${ }^{\mathrm{y}}$ Means within a column and within a season followed by the same letter are not significantly different using LSMEANS comparisons at $P \leq 0.05, \mathrm{n}=10$. 
Table 2. Influence of growing season (spring or fall) and two sources of supplemental foliar $\mathrm{K}$ - a glycine amino acid-complexed $\mathrm{K}$, Potassium Metalosate $(\mathrm{KM})$ and potassium chloride $(\mathrm{KCl})$ applied with or without a surfactant (S) on fructose, glucose, sucrose, total sugars, relative sweetness, and soluble solids concentration (SSC) of netted muskmelon 'Cruiser'.

\begin{tabular}{|c|c|c|c|c|c|c|}
\hline \multirow[b]{2}{*}{ Treatment } & \multicolumn{4}{|c|}{ Sugar $\left(\mathrm{mg} \cdot \mathrm{g}^{-1}\right.$ fresh wt) } & \multirow{2}{*}{$\begin{array}{c}\text { Relative } \\
\text { sweetness }^{z} \\
\left(\mathrm{mg} \cdot \mathrm{g}^{-1} \text { sucrose equiv.) }\right.\end{array}$} & \multirow{2}{*}{$\begin{array}{l}\mathrm{SSC} \\
(\%)\end{array}$} \\
\hline & Fructose & Glucose & Sucrose & Total & & \\
\hline \multicolumn{7}{|l|}{$\overline{\text { Fall } 2004}$} \\
\hline KM & $19.2 \mathrm{a}^{\mathrm{y}}$ & $10.8 \mathrm{a}$ & $33.6 \mathrm{ab}$ & $63.6 \mathrm{~b}$ & $75.7 \mathrm{~b}$ & $9.7 \mathrm{a}$ \\
\hline $\mathrm{KCl}$ & $19.0 \mathrm{a}$ & $11.1 \mathrm{a}$ & $32.1 \mathrm{ab}$ & $62.2 \mathrm{~b}$ & $74.6 \mathrm{~b}$ & $9.2 \mathrm{~b}$ \\
\hline $\mathrm{KM}+\mathrm{S}$ & $17.5 \mathrm{~b}$ & $10.8 \mathrm{a}$ & $41.2 \mathrm{a}$ & $69.5 \mathrm{a}$ & $80.3 \mathrm{a}$ & $9.8 \mathrm{a}$ \\
\hline $\mathrm{KCl}+\mathrm{S}$ & $17.3 \mathrm{~b}$ & $10.0 \mathrm{a}$ & $36.2 \mathrm{ab}$ & $63.5 \mathrm{~b}$ & $74.3 \mathrm{~b}$ & $9.7 \mathrm{a}$ \\
\hline Control & $16.8 \mathrm{~b}$ & $9.9 \mathrm{a}$ & $29.0 \mathrm{~b}$ & $55.7 \mathrm{c}$ & $66.1 \mathrm{c}$ & $8.9 \mathrm{c}$ \\
\hline \multicolumn{7}{|l|}{ Spring 2005} \\
\hline $\mathrm{KM}$ & $14.5 \mathrm{a}$ & $9.4 \mathrm{bc}$ & $31.3 \mathrm{ab}$ & $55.3 \mathrm{a}$ & $64.0 \mathrm{a}$ & $9.6 \mathrm{~b}$ \\
\hline $\mathrm{KCl}$ & $12.9 \mathrm{c}$ & $9.1 \mathrm{c}$ & $31.9 \mathrm{ab}$ & $54.0 \mathrm{a}$ & $61.5 \mathrm{~b}$ & $9.7 \mathrm{~b}$ \\
\hline $\mathrm{KM}+\mathrm{S}$ & $13.8 \mathrm{~b}$ & $9.6 \mathrm{ab}$ & $32.7 \mathrm{a}$ & $56.2 \mathrm{a}$ & $64.2 \mathrm{a}$ & $10.1 \mathrm{a}$ \\
\hline $\mathrm{KCl}+\mathrm{S}$ & $13.8 \mathrm{~b}$ & $10.0 \mathrm{a}$ & $31.5 \mathrm{ab}$ & $55.4 \mathrm{a}$ & $63.3 \mathrm{ab}$ & $9.9 \mathrm{ab}$ \\
\hline Control & $12.4 \mathrm{c}$ & $9.0 \mathrm{c}$ & $29.8 \mathrm{~b}$ & $51.2 \mathrm{a}$ & $56.8 \mathrm{c}$ & $8.8 \mathrm{c}$ \\
\hline
\end{tabular}

${ }^{\mathrm{z}}$ Relative sweetness $=1.8\left(\mathrm{mg} \cdot \mathrm{g}^{-1}\right.$ fresh wt fructose $)+0.7\left(\mathrm{mg} \cdot \mathrm{g}^{-1}\right.$ fresh wt glucose $)+1.0\left(\mathrm{mg} \cdot \mathrm{g}^{-1}\right.$ fresh wt sucrose).

${ }^{y}$ Means within a column and within a season followed by the same letter are not significantly different using LSMEANS comparisons at $P \leq 0.05, \mathrm{n}=10$.

Table 3. Influence of growing season (spring or fall) and two sources of supplemental foliar $\mathrm{K}$ - a glycine amino acid-complexed $\mathrm{K}$, Potassium Metalosate $(\mathrm{KM})$ and potassium chloride $(\mathrm{KCl})$ applied with or without a surfactant (S) on free ascorbic acid (FAA), dihydroascorbic acid (DAA), total ascorbic acid (TAA), and $\beta$-carotene concentrations of netted muskmelon 'Cruiser' fruit.

\begin{tabular}{clllc}
\hline & \multicolumn{3}{c}{ Concn $(\mathrm{mg} / 100 \mathrm{~g}$ fresh wt) } & $\begin{array}{c}\beta \text {-carotene } \\
\left(\mu \mathrm{g} \cdot \mathrm{g}^{-1} \text { fresh wt }\right)\end{array}$ \\
\cline { 2 - 4 } Treatment & FAA & DAA & TAA & $30.9 \mathrm{a}$ \\
\hline Fall 2004 & $12.9 \mathrm{ab}^{2}$ & $23.4 \mathrm{a}$ & $36.4 \mathrm{a}$ & $26.6 \mathrm{c}$ \\
KM & $13.4 \mathrm{a}$ & $20.1 \mathrm{~b}$ & $33.5 \mathrm{~b}$ & $29.6 \mathrm{ab}$ \\
$\mathrm{KCl}$ & $11.9 \mathrm{~b}$ & $23.3 \mathrm{a}$ & $35.2 \mathrm{ab}$ & $28.6 \mathrm{~b}$ \\
$\mathrm{KM}+\mathrm{S}$ & $13.1 \mathrm{ab}$ & $22.8 \mathrm{a}$ & $36.0 \mathrm{ab}$ & $25.7 \mathrm{c}$ \\
$\mathrm{KCl}+\mathrm{S}$ & $10.5 \mathrm{c}$ & $19.5 \mathrm{c}$ & $30.0 \mathrm{c}$ & \\
Control & & & & $22.9 \mathrm{~b}$ \\
Spring 2005 & $7.1 \mathrm{a}$ & $19.6 \mathrm{ab}$ & $26.8 \mathrm{~b}$ & $23.1 \mathrm{~b}$ \\
KM & $6.1 \mathrm{a}$ & $21.9 \mathrm{a}$ & $28.0 \mathrm{ab}$ & $25.1 \mathrm{a}$ \\
KCl & $6.4 \mathrm{a}$ & $21.9 \mathrm{a}$ & $28.3 \mathrm{a}$ & $26.6 \mathrm{a}$ \\
KM $+\mathrm{S}$ & $7.5 \mathrm{a}$ & $19.4 \mathrm{ab}$ & $27.0 \mathrm{ab}$ & $21.8 \mathrm{c}$ \\
KCl $+\mathrm{S}$ & $6.4 \mathrm{a}$ & $17.8 \mathrm{~b}$ & $24.2 \mathrm{c}$ & \\
Control & &
\end{tabular}

${ }^{\mathrm{z}}$ Means within a column and within a season followed by the same letter are not significantly different using LSMEANS comparisons at $P \leq 0.05, \mathrm{n}=10$.

control fruit. Addition of surfactant seemed to increase the effect of foliar $\mathrm{K}$ application on mesocarp tissue $\psi_{\mathrm{p}}(+46 \%$ and $+150 \%$ for $\mathrm{KM}$ and $\mathrm{KCl}$, respectively), although the surfactant effect was not always associated with increased fruit firmness. A weak, but positive correlation was observed between fruit tissue $\psi_{\mathrm{p}}$ and internal fruit firmness $(r=0.259 ; P=0.01)$. The increased $\psi_{\mathrm{p}}$ of K-treated fruit, compared to controls, probably resulted, at least in part, from greater accumulation of other osmolytes (e.g., sugars) besides K in fruit cells. Since there were no differences in tissue $\psi_{\mathrm{w}}$ a more negative $\psi_{\mathrm{s}}$ resulted in higher $\psi_{\mathrm{p}}$ values in $\mathrm{K}$ treated, compared to control fruit. Pressure potential was positively correlated with SSC $(r=0.232 ; P=0.01)$, total sugars $(r=0.276)$, fruit sucrose and glucose concentrations $(P=$ $0.05)$. Total fruit sugars (i.e., osmolytes) were generally higher in $\mathrm{K}$ treated fruit compared to controls and also slightly greater in fall than in spring-grown fruit, and this was associated with slightly higher fruit firmness values in fall than in spring (Table 2). Positive correlations among tissue solute concentration, turgor and firmness have also been reported for potato (Solanum tuberosum L.) tubers (Beringer et al., 1983) and apples (Tong et al., 1999).
Fruit soluble solids concentrations (SSC) were significantly higher in $\mathrm{K}$ treated compared to control fruit in both seasons (Table 2). The positive effect of supplemental K supply on total fruit sugar levels was significant only in fall. Fruit from plants treated with KM also tended to have slightly higher total sugar levels than those treated with $\mathrm{KCl}$ regardless of surfactant use or season. Previous studies on supplemental K fertilization have reported a variety of responses including an increase in fruit sugar levels (e.g., Chapagain and Wiesman, 2004; Daugaard and Grauslund, 1999; Johnson et al., 1998), no effect on fruit SSC (Flores et al., 2004; Hartz et al., 2001) and improved yields (Hartz, 2005). Hartz et al. $(2001,2005)$ found that $\mathrm{K}$ fertigation reduced the incidences of yellow shoulder and internal white tissue disorders in tomato but did not influence fruit SSC or juice color. They attributed the absence of any response of fruit SSC to other overriding factors such as cultivar, irrigation management which potentially masked any K effects. Lin et al. (2004) found that supplemental $\mathrm{K}$ fertilization of melon in soilless culture increased fruit sucrose content but had no effect on fruit fructose and glucose concentrations. In the present study, however, netted muskmelon fruit sucrose, glucose and fructose levels were generally increased by supplemental foliar K fertilization. It is worth noting that foliar KM treatments without surfactant tended to have higher fruit fructose concentrations than those with surfactant. A plausible explanation for this observation is that the surfactant interfered with the catalytic role of amino acids on invertase activity. Acid invertase (EC 3.2.1.26), an enzyme found in melon fruit (Lester et al., 2001), responsible for sucrose hydrolysis to fructose and glucose, uses amino acids to play a catalytic role in the hydrolysis reaction(Quick and Schaffer, 1996). It is possible that the surfactant interfered with the catalytic activity of the amino acid, thus down-regulating acid invertase and allowing sucrose phosphate synthase (EC 2.3.1.14), the sucrose-synthesizing enzyme in melons (Lester et al., 2001), to remain active. Sucrose phosphate synthase specifically utilizes $\mathrm{K}$ as a cofactor to synthesize sucrose from glucose and fructose (Lester et al., 2001). The relative levels of sucrose and fructose in fruit also have important implications for consumer preference since fructose is perceived to be up to $80 \%$ sweeter than sucrose. In the current study, the relative sweetness of melons was increased by supplemental foliar K applications compared to controls (Table 2). In fall, total fruit sugars of $\mathrm{K}$-treated fruit were significantly higher than those of control fruit. A similar trend was also observed in spring, although not significant. More importantly, the fructose:sucrose ratio was increased significantly by supplemental foliar $\mathrm{K}$ applications in both seasons. This indicates that supplemental foliar $\mathrm{K}$ fertilization has the potential to improve a key consumer preference attribute of muskmelons.

Free ascorbic acid, dihydroascorbic acid, total ascorbic acid and $\beta$-carotene were generally higher in fruit treated with $\mathrm{K}$ than in control fruit (Table 3). However, there were no consistent $\mathrm{K}$ source effects on these quality parameters. The beneficial effects of supplemental $\mathrm{K}$ probably resulted from a combination of improved leaf photosynthetic $\mathrm{CO}_{2}$ assimilation, assimilate translocation from leaves to fruit, improved leaf and fruit water relations, increased enzyme activation and substrate availability for ascorbic acid and $\beta$-carotene biosynthesis all associated with adequate K nutrition (Gross, 1991; Hopkins, 1963). In general, use of a surfactant tended to increase fruit tissue concentrations of ascorbic acid and $\beta$-carotene, however, the surfactant effect was not always consistent with both $\mathrm{K}$ forms. Use of foliar applied $\mathrm{K}$, as a means to improve the antioxidant capacity (ascorbic acid and $\beta$-carotene, respectively) of melon fruit is a readily applicable, low-technology approach to improve the human wellness attributes of current commercially available melon cultivars.

The beneficial effects of supplemental foliar $\mathrm{K}$ applications on melon fruit quality parameters were consistently positive regardless of growing season-spring or fall. However, fruit produced in fall had higher fruit firmness, ascorbic acid, $\beta$-carotene, total sugars and SSC (Tables 1, 2, and 3). Mechanisms for the 
improved quality parameters in fall compared to spring-grown fruit are still uncertain since average daily temperatures and cumulative heat units were slightly higher in fall (about $33^{\circ} \mathrm{C}$ and 728 , respectively) than in spring (about 28 ${ }^{\circ} \mathrm{C}$, 601). Cumulative photosynthetic photon flux during fruit development (from pollination to final harvest) was higher in Spring (982 $\left.\mathrm{mol} \cdot \mathrm{m}^{-2}\right)$ than in fall $\left(637 \mathrm{~mol} \cdot \mathrm{m}^{-2}\right)$. A common production problem not observed in this study, which is likely temperature and humidity related, is the foliar burning effect, which is frequently observed when using foliar applied salts such as $\mathrm{KCl}$ (Swietlik and Faust, 1984). Burning of leaves occurs when salts accumulate on and are not absorbed. Rates of absorption are highest when relative humilities are $80 \%$ or higher (Schonherr and Luber, 2001). Application of all $\mathrm{K}$ treatments in this study occurred at about $0800 \mathrm{~h}$ when glasshouse temperatures were relative low (about $23{ }^{\circ} \mathrm{C}$ ) and relative humidity was highest (about $85 \%$ ).

In summary, supplementing soil $\mathrm{K}$ with foliar $\mathrm{K}$ applications during muskmelon fruit development and maturation improved fruit quality by increasing firmness, sugar content, ascorbic acid, and $\beta$-carotene levels. Differences between the two K sources (an organic form, $\mathrm{KM}$ and an inorganic form, $\mathrm{KCl}$ ) were minimal and use of a surfactant tended to have a positive effect on the response to supplemental foliar $\mathrm{K}$ applications. These quality improvements were obtained by implementing a simple management tool (foliar applied K using generally available $\mathrm{K}$ compounds plus a surfactant) that growers can adopt all over the world.

\section{Literature Cited}

Beringer, H., H.E. Haeder, and M. Lindhauer. 1983. Water relationships and incorporation of ${ }^{14} \mathrm{C}$ assimilates in tubers of potato plants differing in potassium nutrition. Plant Physiol. 73:956-960.

Beringer, H., K. Koch, and M.G. Lindhauer. 1986. Sucrose accumulation and osmotic potentials in sugar beet at increasing levels of potassium nutrition. J. Sci. Food Agr. 37:211-218.

Boyer, J.S. 1969. Measurments of the water status of plants. Ann. Rev. Plant Physiol. 20:351-364.

Brady, N.C. 1984. Supply and availability of phosphorus and potassium, p. 327-362. In. N.C. Brady (ed.). The nature and properties of soils. 9 ed. MacMillan Publ. Co., New York.

Chapagain, B.P. and Z. Wiesman. 2004. Effect of Nutri-Vant-PeaK foliar spray on plant development, yield, and fruit quality in greenhouse tomatoes. Sci. Hort. 102:177-188.

Cooke, D.L. and D.T. Clarkson. 1992. Transport and receptor proteins of plant membranes: molecular structure and function. Plenum Press, N.Y.

Daugaard, H. and J. Grauslund. 1999. Fruit colour and correlations with orchard factors and postharvest characteristics in apple cv. Mutsu. J. Hort. Sci. Biotechnol. 74:283-287.

Flores, P., J.M. Navarro, C. Garrido, J.S. Rubio, and V. Martinez. 2004. Influence of $\mathrm{Ca}^{2+}$ and $\mathrm{NO}_{3}^{-}$fertilization on nutritional quality of pepper. J. Sci. Food Agr. 84:569-574.

Glenn, G.M. and B.W. Poovaiah. 1990. Calciummediated postharvest changes in texture and cell wall structure and composition in 'Golden Delicious' apples. J. Amer. Soc. Hort. Sci. 115:962-968.

Gross, J. 1991. Carotenoids, p. 75-278. In: J. Gross (ed.). Pigments in vegetables: Chlorophylls and carotenoids. Van Nostrand Reinhold, N.Y.

Hartz, T.K., E.M. Miyao, R.J. Mullen, and M.D. Cahn. 2001. Potassium fertilization effects on processing tomato yield and fruit quality. Acta Hort. 542:127-133.

Hartz, T.K., P.R. Johnstone, D.M. Francis, and E.M. Miyao. 2005. Processing tomato yield and fruit quality improved with potassium fertigation. HortScience 40:1862-1867.

Hopkins, F. 1963. Vitamin C, p. 205-210. In: J.B.S. Braverman (ed.). The biochemistry of foods. Elsevier, New York.

Howard, D.D., C.O. Gwathmey, and C.E. Sams. 1998. Foliar feeding of cotton: Evaluating potassium sources, potassium solution buffering, and boron. Agron. J. 90:740-746.

Johnson, D.S., T.J. Samuelson, K. Pearson, and J. Taylor. 1998. Effects of soil applications of potassium sulphate on the mineral composition and eating quality of stored 'Conference' and 'Doyenne du Comice' pears. J. Hort. Sci. Biotechnol. 73:151-157.

Lester. G.E. and M.A. Grusak. 1999. Postharvest application of calcium and magnesium to honeydew and netted muskmelons: Effects on tissue ion concentrations, quality and senescence. $\mathrm{J}$. Amer. Soc. Hort. Sci 124:545-552.
Lester, G.E., L. Saucedo Arias, and M. Gomez Lim. 2001. Muskmelon fruit soluble acid invertase and sucrose phosphate synthase activity and polypeptide profiles during growth and maturation. J. Amer. Soc. Hort. Sci. 126:33-36.

Lester, G.E., J.L. Jifon, and G. Rogers. 2005. Supplemental foliar potassium applications during muskmelon fruit development can improve fruit quality, ascorbic acid, and $\beta$-carotene contents. J. Amer. Soc. Hort. Sci. 130:649-653.

Lin, D., D. Huang, and S. Wang. 2004. Effects of potassium levels on fruit quality of muskmelon in soilless medium culture. Sci. Hort. 102:53-60.

Marschner, H. 1995. Ion uptake mechanisms of individual cells and roots: Short-distance transport, p. 6-78. In: H. Marschner (ed.). Mineral nutrition of higher plants 2nd ed. Academic Press, New York.

Mengel, K. and E.A. Kirkby. 1980. Potassium in crop production. Adv. Agron. 33:59-110.

Quick, W.P. and A.A. Schaffer. 1999. Sucrose metabolism in sources and sinks, p. 115-156. In. E. Zamski and A.A. Schaffer (eds.). Photoassimilate distribution in plants and crops: Source and sink relationships. Marcel Dekker Inc., New York.

Schonherr, J. and M. Luber. 2001. Cuticular penetration of potassium salts: Effects of humidity, anions, and temperature. Plant Soil 236:117-122.

Shackel, K.A., C. Greve, J.M. Labavitch, and H. Ahmadi. 1991. Cell turgor changes associated with ripening in tomato pericarp tissue. Plant Physiol. 97:814-816.

Swietlik, D. and M. Faust 1984. Foliar nutrition of fruit crops, p. 287-356. In. J. Janick (ed.). Horticultural reviews. vol. 6, AVI, Westport, Conn.

Tisdale, S.L., W.L. Nelson, and J.D. Beaton. 1985. Soil and fertilizer potassium, p. 249-291. In. S.L. Tisdale, W.L. Nelson, and J.D. Beaton (eds.). Soil fertility and fertilizers. 4th ed. MacMillan Publ. Co., New York.

Tong, C., D. Krueger, Z. Vickers, D. Bedford, J. Luby, A. El-Shiekh, K. Shackel, and H. Ahmadi. 1999. Comparison of softening-related changes during storage of 'Honeycrisp' apple, it parents, and 'Delicious'. J. Amer. Soc. Hort. Sci. 124:407-415.

Williams, L. and U. Kafkafi. 1998. Intake and translocation of potassium and phosphate by tomatoes by late sprays of $\mathrm{KH}_{2} \mathrm{PO}_{4}(\mathrm{MKP})$, $\mathrm{p}$. 85-90. In: M.M. El-Fouly, F.E. Abdalla, and A.A. Abdel-Maguid (eds.). Proceedings of the symposium on foliar fertilization: A technique to improve production and decrease pollution, 10-14 Dec. 1995, NRC, Cairo. 